\title{
Research on Information Disclosure of County-Level Government Portal Websites -- Taking the County Government of Xi'an as an Example
}

\author{
Fang Zhou and Lujian Sun \\ No. 1 Xuefu Avenue, Changan District, Xi'an \\ 719220094@qq.com
}

Keywords: Information disclosure; Xi'an; County government; Government portal

\begin{abstract}
This paper investigates and analyzes the information disclosure module of county-level government portal in 13 districts and counties under the jurisdiction of Xi'an with literature research method and case analysis method. It is found that there are problems such as incomplete information disclosure content, slow updating speed, lack of supervision and inspection, etc. In order to solve the existing problems and shortcomings, we propose to optimize the information disclosure management system of the county-level government, improve the supervision mechanism, and change the concept of information disclosure subject of the county-level government to perfect the information disclosure of county-level government portal websites of Xi'an, in order to provide help for the future optimization of these websites.
\end{abstract}

\section{Introduction}

Information disclosure is an important measure for the government to realize the transformation of its functions, improve its management ability and public service capability, and it is also an important means to protect citizens' right to information. The government portal is an important channel for information disclosure and the first window. Local governments at the district and county level have the function of a link between the cities under the jurisdiction of the county and cities under the jurisdiction of the government. The quality of the information disclosure on the portal site directly affects the governance effect of grassroots democracy in our country and the level of economic and social development.

The academic research on government information disclosure is quite adequate at present, but there is a lack of research on online disclosure of county government information. In this paper, we regard the county-level government portals in Xi'an as the research object, and investigate the issue of information disclosure in the government portals in order to promote the construction of county-level local government portals in Xi'an.

\section{The County-Level Government Information Disclosure Status Quo in Xi'an}

Xi'an has jurisdiction over 11 districts such as New town area, Beilin District, Lianhu District and two counties: Lantian County, and Zhouzhi County. By the end of 2010, the county governments in these 13 districts have all built their own government portals.

\section{The Information Disclosure of Government Portal Websites in Various Districts and Counties of Xi'an.}

The Number of Information Disclosure. The number of government information disclosure is composed of the number of active public information and the number of public information by application. The survey finds that although 13 county-level governments have been open, the number of public numbers is far apart, as shown in the following table. 
Table 1 County-level government information disclosure statistics (2017)

\begin{tabular}{|c|c|c|c|c|}
\hline Government & $\begin{array}{c}\text { The number } \\
\text { of active } \\
\text { public } \\
\text { information }\end{array}$ & $\begin{array}{c}\text { The number of } \\
\text { public information } \\
\text { by application }\end{array}$ & $\begin{array}{c}\text { The number of } \\
\text { invisible } \\
\text { information }\end{array}$ & $\begin{array}{c}\text { The number of } \\
\text { applications for } \\
\text { administrative } \\
\text { reconsideration }\end{array}$ \\
\hline New town area & 10143 & 22 & 0 & 19 \\
\hline Beilin District & 8660 & 34 & 0 & 0 \\
\hline Yanta District & 8459 & 41 & 0 & 1 \\
\hline Lianhu District & 10131 & 14 & 0 & 0 \\
\hline Chang'an District & 18861 & 63 & 0 & 7 \\
\hline Huyi District & 4086 & 12 & 0 & 0 \\
\hline Yanliang District & 10137 & 7 & 0 & 0 \\
\hline Weiyang District & 36036 & 0 & 0 & 0 \\
\hline Gaoling District & 9821 & 2 & 0 & 3 \\
\hline Baqiao District & 26997 & 49 & 0 & 0 \\
\hline Lintong District & 8675 & 125 & 0 & 0 \\
\hline Lantian County & 6011 & 6 & 0 & 0 \\
\hline Zhouzhi County & 6895 & 3 & 0 & 0 \\
\hline
\end{tabular}

The Quality of Information Disclosure. The core of information disclosure lies in the content, while the quality of the content is especially important. The key to the quality of information disclosure is whether the public content has any real meaning or not, and whether it is the information really needed by the public.

In terms of the information disclosure provided by all county-level governments in Xi'an, there are abundant public contents in the information disclosure of some government basic situations, such as government official documents, division of labor and leadership, laws and regulations, etc. There is regular information disclosure. The decision-making information is relatively small, such as government procurement, supervision and inspection. Although each site has a platform for providing such information, the frequency of updates and the amount of information provided are limited. Some government websites only publish original, unprocessed information, while less sensitive information is published. Obviously, this information cannot meet the deep needs of the public.

\section{The Operation of Information Disclosure}

The update speed of information disclosure columns. The speed of updating the portal is a reflection of its vitality, and it also conveys the importance of the government's attention to the construction of the website and the disclosure of information.

The survey shows that the surveyed websites of 13 districts and counties in Xi'an have different levels of dynamic information dissemination. Most of the county governments abide by the information disclosure timeliness requirements. They can release information at all levels of government work at the first time through the news section and department dynamics.

But the survey found that some of the portal sites are also old and lagging. There are 3 portals in Baqiao District, Gaoling District, Lantian County, and the update speed is clearly not enough timely, such as the safety production, social livelihood, urban and rural construction, and other common public information modules related to the fundamental interests of the people. The new content is kept in a month to two months ago. Instead, it is the leading activities and the majority of the news, and less practical information. 
Explicit Guidance for the Columns of Information Disclosure. The guidance of the government portal is mainly embodied in the two aspects of the government information disclosure guide and the public directory. According to the author's investigation, the information disclosure guidelines of 13 county-level governments in Xi'an include the classification of government information, the way to get it, the necessary contents of the government information disclosure institution's name, office address, contact telephone and so on. The guide is comprehensive and clear, and provides a convenient way for users to use the site to get the information they need.

For the information public directory, most of them have a clear division of the catalogue, which will make the basic information open and the key information clear. For example, the index, name and important content of government information are set up in the new town area and Lianhu District. But there are also some county-level government websites that do not have a clear classification of the public information, but a unified list of the pages of the public information. This will sometimes increase the difficulty of the user's use, which is not conducive to the public information of the government.

The Information Disclosure Online Service and the Interaction of Government and People. Although "government-citizen interaction" and "information disclosure" are two modules of the government portal, they are inseparable. Only through interaction with the public can we fully understand public opinion and know what they care about most and think most, so that people know the difficulty of access to relevant information.

Through the investigation, it is found that in the interaction with the public, most of the county-level government portal websites in Xi'an are in the state of one-way information release. Although each government's portals explicitly set up an interactive platform, the interaction with the public is still in a relatively weak state, especially on the module of information disclosure. Moreover, most websites interact with each other for a long time. For example, electronic automatic windows cannot get the information they need, and enter into the service window, and the efficiency is low.

When it comes to the "interactivity" of information disclosure, we have to apply for an open platform. The survey found that there are still a series of problems in the public platform of the county governments. First of all, the popularity of online submission system is relatively low. Although some government departments have provided online application system or e-mail application mode, they cannot submit smoothly. Some government departments only accept written applications on the spot. Secondly, some websites cannot reply within the legal period, and some reply, but the content of the reply is not related to the application. Some departments also procrastinate on the grounds of the responsible personnel travel, the need to ask for the instructions of the leadership and so on.

\section{The Problems and Reasons for the Information Disclosure of the Portal Websites of the County Governments in Xi'an}

Existing Problems. Based on the above statistics, we can see that the level of Xi'an county government portal information disclosure is in continuous improvement, the construction of information disclosure system is gradually improved, but there are still many shortcomings compared to the requirements of the national regulations and the social public, mainly reflected in the following aspects.

The classification of information is not reasonable, and the public is inconvenient to obtain it. Part of the county-level government portal column navigation is not clear, there are overlapping topics in the column theme and the issue of information and the theme of the column are not consistent.

The important information is not updated in time, and the timeliness is poor. According to the survey of the portal websites of the county-level governments in Xi'an, the government information update is timely, basically in strict accordance with the requirements on time update, but update in economic and social development of public interest is relatively poor.

The distribution of information resources is uneven, and the content of the people's real concern 
is less open.

Information disclosure has a series of problems, such as unclear supervision responsibility, supervision surface and lack of external supervision.

\section{Analysis of the Causes of the Problems}

"Official Standard" Thought is Ingrained. The key factor that restricts the information publicity of Xi'an county governments is the value concept of the public authorities, and their attention to information publicity is weak.

The "official standard" idea of the ruling party is ingrained. "Official standard" is a kind of value concept taking the official as the base and taking the official as the honourable man, and it still remains in some county-level areas. If the government website operation is bad or news update is lagging behind, unable to communicate with people and interact with each other, then we must find out the reason of the main body of the portals -- the government department. The ruling party is the leading force to master the public operation and development of government information. Some officials do not care whether government information disclosure can achieve substantial results. They simply follow the requirements of their superiors, and make government information public just as a task assigned by superiors.

Local Government Information Management is Extensive. Administrative information management is an activity process for government departments to manage administrative information and information activities in order to achieve administrative objectives and take modern information technology as a means. The purpose is to realize the rational allocation of administrative information and effectively meet the needs of government departments and social information. The information disclosure of local government belongs to a part of administrative information management.

At present, the administrative information management of our country is in the exploration stage, and most of it is only the network and electronic translation of the existing management process. The management mode still divides the "Pyramid" structure based on the government from top to bottom to divide the management level and the management range. The orders issued by the government are conveyed one by one from top to bottom, and the public and business applications need to be examined and approved from bottom to top. Therefore, in the process of information flow, each link will cause a certain degree of information distortion. The greater the scope of the extensive management model, the higher the cost, and the lower the efficiency.

Therefore, due to the extensive mode of information management, there are various problems in each county government information disclosure, such as the poor response to the citizens, poor timeliness of information disclosure. The distribution of public government information is scattered, and the systematic platform of public government information is not formed, which ultimately affects the effect of citizens' access to government information.

Supervision and Evaluation Mechanism is not Perfect. As an important information resource in social life, whether government information can be disclosed timely and effectively in accordance with the law is related to whether the behavior of relevant government departments can be effectively supervised. Since the promulgation of the "regulations" in 2008, all levels of government have made some progress in the information disclosure. However, there are still some shortcomings in the disclosure of information, such as lack of supervision and guarantee mechanism.

The initiative and open oversight mechanism is weak and the application openly encounters resistance. Although the "regulations" stipulate many obligations and responsibilities of the public subjects, the mechanism of accountability is too "gentle." In the supervision and inspection module, the county-level government made a series of macro-regulations on the examination system, annual report and administrative violation of rules, but there is no clear definition on how to ensure the specificness of timeliness and completeness of government information disclosure. 


\section{Countermeasures and Suggestions on the Information Disclosure of Government Portal Websites in Xi'an County}

Changing the Concept of County-Level Government Information Open Main Body. To make the government's information public really play its due role, the leaders of government departments and their staff should change their inherent concepts. First of all, government agencies and their staff should fundamentally change their traditional "official position". Relevant staff members of government agencies should realize that they can grasp a great deal of government information as the power vested in them by the people and the constitution, and that it is their obligation to make public the necessary government information in real time and effectively. Therefore, the government should establish a "people-oriented" concept and actively build a sunshine-type and transparent government service to safeguard the people's right to information and the right to participate in the deliberations and administration of state affairs. Second, government agencies and their staff should change their understanding of government portals. They should realistically recognize the positive role played by portals in opening government information, enhancing the interaction and communication between the government and the people and promoting the transformation of government functions. Therefore, it is also necessary for government departments to step up training of staff members who disclose information, change their concepts and serve the people.

Improving the County-Level Government Information Disclosure Management System. First of all, all county-level governments should formulate and perfect the information disclosure management system in line with their own development according to the actual conditions in all regions, set up special information disclosure agencies and give corresponding responsibilities and authorities to the relevant staff members so that they can really play a unified and coordinated role, and the professionals who are skilled in management and technology should be equipped to build and manage government websites, and promote the sustainable development of government portal website and information operation.

Second, they should improve the review and release mechanism of government information disclosure to prevent the public not to disclose information on the grounds of confidentiality. They should establish a standardized procedure for the public release of information so as to make it follow the rules and avoid repetitiveness and blindness of relevant work, reduce the operating costs of information disclosure, and achieve a balance of democracy and efficiency.

Perfecting the Supervision Mechanism and Establishing the Incentive Mechanism for Public Assessment of Government Information. At present, every county government in Xi'an is still based on internal supervision, and external supervision is supplemented. When it comes to internal supervision, every county government should set up a special supervision institution, which is responsible for the internal supervision of information disclosure, equipped with special staff members to stick to the supervision work, and supervise the supervisors in the department not to serve other departments. Secondly, the county governments should have a set of punishment mechanism for information disclosure, give some punishment measures to the staff that are dereliction of duty, and play a certain role of restriction and supervision. Thirdly, the annual assessment is carried out. The methods of assessment can be carried out by means of self-examination, special inspection and comprehensive evaluation. Finally, the regulators should strengthen their own binding force and does not abuse supervision power, so as to be effective in supervision.

The practice has proved that external supervision is more effective than internal supervision. Therefore, the government portal website should give full play to the supervision of the public and the external mass media. They should pay more attention to the complaints and suggestions of the media and the public, pay attention to the problems and solve the problems in time so as to improve the public opinion collection, suggestions, online consulting, and online complaints modules. Therefore, they should strengthen the interaction and communication between the government and the people, listen to the voices of the people and give full play to the role of government information disclosure. 


\section{References}

[1] X.C.Chen:Chinese Government Website Construction and Application,Vol. 43 (2016) No.3, p. 210.

[2] H.Liu: Government Information Disclosure System,Vol. 21 (2014) No.6, p.15.

[3] F.Wang Fang:The government under the sun: the path and incentives for government information behavior, Vols. 21-24 (2006) No.6, p.15.

[4] X.W.Du:Information Disclosure of Grass-Roots Government: Problems, Causes and Countermeasure, Vol. 26 (2011) No.6, p.7.

[5] X.H.Gu:Research on Some Problems of Information Service of County-level Government Websites in China - Based on the Investigation and Analysis of Information Services Provided by Websites of Tangshan County Government, Vol. 26 (2011) No.6, p.87.

[6] J.Y.Zhang: An Empirical Study on Information Disclosure of Shaanxi Provincial Government ,Vol. 43 (2011) No.7, p.124.

[7] D.Liang: Network Politics and Government Portal Development, Vol. 43 (2014) No.10, p.166.

[8] Q.Gao:"The People's Republic of China Government Information Disclosure Ordinance," the second anniversary of the experience and reflection, Vols. 21-24 (2010) No.9, p.151.

[9] W.Fang and W.Xiang:Local Government Website Information Disclosure Ability Evaluation Index System Construction and Application of Cut, Vol. 43 (2011) No.4, p.66.

[10] J.Wang:Research on the Improvement of County Government Online Information Disclosure Based on Ward System Clustering,Vol. 21 (2016) No.7, p.92. 